The politics of managing a World Heritage Site: The complex case of Hadrian's Wall

Victoria R Bell

Social Futures Institute, Teesside University, Middlesbrough, UK.

Social Futures Institute

Teesside University

Middlesbrough

UK

TS1 3BA

Email: Victoria.Bell@tees.ac.uk

Accepted for Leisure Studies 2012 


\section{The politics of managing a World Heritage Site: The complex case of Hadrian's}

\section{Wall}

Managing sites that cover large areas or have multiple designations within their boundary can be challenging, particularly if several organisations are responsible for managing different aspects of the site. Hadrian's Wall World Heritage Site (WHS) was designated for its archaeological importance which is of universal significance. The management of Hadrian's Wall is formalised in the WHS Management Plan (2008-2014) which aims to cover different objectives, with archaeology at the core of management.

This article draws on management documents of the WHS, established visitor planning frameworks and qualitative interviews with managers along Hadrian's Wall to discuss the evolution of a values-based management approach.

It is evident that managers have to balance different values, priorities and interests, and make trade-offs when they work in partnership on a multiple-use site so that conflicts can be resolved - and whilst this may look straightforward on paper, in practice, it can be much more difficult for institutions and individuals to compromise their own professional or personal values. Despite its challenges, this article advocates a values-based, or pluralistic, management approach as the most effective means of managing multiple-use sites, resolving management conflicts and working in partnership to agreed outcomes.

Keywords: values-based management; countryside management; World Heritage Site; tourism; management plan. 


\section{Introduction}

Managing sites that cover large areas or have multiple designations within their boundary can be challenging, particularly if several organisations or agencies are responsible for managing different aspects of the site with various objectives. There are currently 911 World Heritage Sites (WHSs) worldwide, 28 in Great Britain and Northern Ireland, all considered to be of 'outstanding universal value' for their cultural, natural or mixed (or a combination of both) significance. ${ }^{i}$ Thus, many of these Sites will have multiple uses - but how best to manage a site so that it meets the needs of its users? This article advocates a values-based management approach as the most effective means of managing multiple-use sites. The approach encourages a means of resolving management conflicts when a range of stakeholders with different priorities are working in partnership. In order to examine how management of a WHS evolves over time, the article uses Hadrian's Wall WHS in the UK as the example, and a case study within the WHS to explore the success of a values-based approach in practice. The case study presents data from a critical time in the management of the WHS (2005-2006): the National Trail ${ }^{\mathrm{ii}}$ had been open for two years and the 'new' management plan (2008-2014) was in preparation. This facilitates a retrospective examination of how the challenges raised in the case study have been resolved and considered in the main strategic document for the Site.

\section{Hadrian's Wall}

Hadrian's Wall was designated as a WHS by the United Nations Educational, Scientific and Cultural Organisation (UNESCO) in 1987 for its archaeological and historic importance as, 'the most complex and best preserved of the frontiers of the Roman Empire' (Hadrian's Wall Heritage Ltd [HWH], 2008a:7). Its construction 
was ordered by the Emperor Hadrian after a visit to Britain in AD122 and took approximately ten years to complete (Turley, 1998). Aside from being a WHS and archaeologically significant, the Wall crosses some dramatic landscapes. Both of these factors contribute to its importance as a tourist destination; tourism is an economic driver in some areas of the WHS.

Hadrian's Wall is 73 miles long and runs across northern England from Wallsend, near Newcastle upon Tyne in the east, to Bowness on Solway in the west (Birley, 1976; Breeze, 2006) (see Figure 1, or HWH, 2008a for a set of detailed maps). Hadrian's Wall WHS covers a much larger area as it includes a buffer zone either side of the Wall and continues down the Cumbria coast to Ravenglass, making the WHS approximately 150 miles long, covering about 200 square miles. It is a complex collection of archaeological excavations (including forts, milecastles and turrets), earthworks and unconsolidated ruins. Hadrian's Wall was built of stone in the east and turf in the west. Although these earthworks and excavations are evident in places along the length of Hadrian's Wall, only about seven per cent of excavated or reconstructed Wall is visible $(\mathrm{HWH}, 2008 \mathrm{a})$. This discussion concentrates on the central area of Hadrian's Wall and builds on evidence collected in this part of the WHS. For the purposes of this article, the central section of the WHS is considered to be the area between Greenhead and Chollerford (approximately 17 miles and oneeighth of the WHS) and as shown in Figure 1, includes several major Roman sites. It introduces the process of values-based management and uses a specific case study on the Wall to illustrate how a values-based philosophy is converted into practical application - exploring how conflict of interest and different objectives endeavour to work together to an agreed outcome. 


\section{[Figure 1 inserted somewhere near here]}

As with any site that either has multiple designations or covers a large area, management requires cooperation and collaborative working to achieve best results. Management plans are therefore essential for setting out a framework of policies, management objectives and guidelines for a site to maintain sustainability (Bromley, 1990; Garrod \& Whitby, 2005; Mason, MacLean and de la Torre 2003). Management plans are a requirement by UNESCO for all WHSs. Other agencies and organisations will have their own strategic and work plans for areas within the Site and designations will have discrete objectives and priorities, which can often conflict. For example, National Park designation relates to access, conservation and recreation, while Areas of Outstanding Natural Beauty do not have a specific responsibility to create opportunities for recreation. Recreational activities are allowed within these areas as long as they do not conflict with conservation, agriculture or forestry (Garrod \& Whitby, 2005). Sites of Special Scientific Interest (SSSI) are protected by legislation as they are internationally important for their wildlife or geological features. There are many statutory designations within Hadrian's Wall WHS. For example, the central section of the Wall is in the southern part of Northumberland National Park. Some of the west coast of the WHS is in the Solway Coast AONB. There are also SSSIs which include the Wall Loughs and Walltown is a nature conservation area. The Hadrian's Wall Path National Trail like the Wall crosses the country from Wallsend to the Solway, though in some places, due to statutory designations, land agreements and preservation of the archaeology, does not always follow the actual line of the Wall. Much of the land that Hadrian's 
Wall crosses is privately owned by approximately 700 different owners, a large majority of which are farms and there are ' 17 public, private or voluntary bodies directly involved in its management' (HWH, 2008b: 8; Mason et al., 2003). These stakeholders have their own interests and priorities and range from international down to communities and individuals and include agriculture, tourism, small businesses and archaeological interests. Furthermore, a single organisation can be responsible at different tiers of the management structure. For example, English Heritage, as the Government organisation with the duty to protect and conserve, has overall responsibility for the protection and conservation of the WHS. English Heritage also manages three sites along Hadrian's Wall: Chesters, Corbridge and Housesteads. Furthermore, English Heritage owns and manages Birdoswald, a fort and museum on the western-central part of the Wall (see Figure 1). In short, cooperation and collaboration is a fundamental requirement for the management of Hadrian's Wall.

This article is concerned with the complex process management of an area that has multiple stakeholders, rather than the disciplinary based scientific management of archaeological sites. The primary objective of Hadrian's Wall WHS is preservation of the Roman remains. The archaeology is at the core of the designation and so, in times of dispute, it is probable that the archaeology will take precedence. Taken in isolation this would not be an issue. However, it is rare that a practical land management decision does not impact on another concern or activity, and so in this case, other significant values of the WHS. For example, what may be good for the archaeology may have a devastating effect on a rare habitat or species within that habitat or be detrimental to the landscape. Due to the plurality of 
stakeholder interests, I argue that producing standard management solutions are not generally possible, even in the short term. Instead arrangements are characterised by a requirement for partnerships and sometimes unwelcome compromise. The article is divided into five sections. Section one discusses values-based management approaches. It sets out the conceptual approach adopted in this article, following Elson, Heaney and Reynolds (1995), for management plans and their use in land management. Section two provides a description of the methodology used for the research and section three explains how the management strategy for Hadrian's Wall has evolved, by widening the values of the Site and what this means for the WHS. The fourth section presents analysis of empirical evidence to explore the efficacy of a values-based approach, using a detailed case study to evidence how it can work in practice. The conclusion summarises my argument for a pluralistic approach, making decisions through negotiations and continued dialogue of value judgements and trade-offs, and explains how such an approach can be applied to other multiple-use sites.

\section{Managing multiple-use sites}

Values-based management originated in conventional organisational management theory and practice and represents a shift from focusing on the views of one stakeholder, to the aim of considering the views of all stakeholders and working towards a shared vision (Anderson, 1997; London, 1999). In doing so, values-based management promotes increased accountability and transparency, particularly with social and environmental issues that are becoming increasingly important for corporate social responsibility (Pruzan, 1998). Value pluralism originates from political philosophy and rather than use monetary value models such as contingent 
valuation or cost-benefit analysis, it attempts to explain how people deal with having to make trade-offs based on their own values through negotiation (Chambers \& Carter, 2008; Galston, 2002; Tetlock, 1986; Tetlock, Peterson \& Lerner, 1996). Idealistically, value pluralism balances all interests equally - in practice this is difficult to achieve. An area such as a WHS that is selected for its universal value archaeology in the case of Hadrian's Wall - and that has further statutory designations within the area can present particular tensions and complexities for management. As Church, Gilchrist and Ravenscroft (2007:219) state “...differences in social values and moral standpoints structure the debates over conflict" and the difficulty lies in agreement of these trade-offs for stakeholders; fear of wrong decisions and setting precedents can delay or even halt agreements being made (Church, Gilchrist \& Ravenscroft, 2004; O’Neill, 1997; Tetlock et al., 1996). Furthermore, what may seem like a reasonable trade-off in one situation and place may be completely unreasonable in another setting or at another time (Galston, 2002; Tetlock et al., 1996) - and taking responsibility for these actions may be difficult for some. For organisations that operate for financial gain, the aim for all stakeholders is somewhat simplified. For organisations that manage land, landscape and activities within that landscape - for example a public park or National Park where stakeholders and users will be innumerable - balancing the needs of stakeholders can be composite. Furthermore, there is an inherent problem with putting a financial value on heritage objects, and even more difficult with intangible heritage (Carman, 2000).

Management plans, and so management of an area, and the organisations charged with the task of doing so, have to be able to integrate processes that can both 
adapt to and initiate change, such as political, cultural and environmental changes and also to the changing needs of the groups that they represent (Bromley, 1990; Garrod and Whitby, 2005). For Hadrian's Wall management the core, or shared values, begins with the archaeology. Traditional approaches to site management focus on one perspective, or interest, without fully taking into account the consequences of conserving one aspect over another.. This is not a criticism of this approach - in the right situation it may be the most appropriate approach to take, however, misunderstandings can lead to conflicts and in some cases irreconcilable differences (for e.g. see Church et al., 2007; Gilchrist \& Ravenscroft, 2011). In a mixed-use site, whatever the core value of the site, other views and values have to be accounted for to gain consensus and a beneficial result not just for stakeholders, but also importantly, for the site. It is not only about the resource or use of resources, but how best to manage them.

A WHS such as Hadrian's Wall provides an example of where different institutions, organisations and individuals with conflicting values and interests work together with a shared vision of managing the WHS (or areas within it) sustainably. Although stakeholders have this shared vision and knowledge of the core values of the WHS, they have discrete philosophies and work practices which can impinge on these values. These can include site evaluation and descriptions of significance, which can lead to conflicts in land use. Conflicts of interest, between both different users and managers or landowners, of sites and areas is a continuing issue in recreational spaces, (Church et al., 2007), with viewpoints based on personal meaning; different expectations of the site, and the resource; and, individuals and groups giving their own interests and principles priority (Jacob and Schreyer, 1980; 
Ravenscroft, 2004). Conflicts and issues will be different in each circumstance, interests may overlap, making the situation complex and multi-dimensional (Ravenscroft, 2004). In this case, the management plan is a common framework to which all organisations can work. As a strategic document, a management plan does not necessarily eliminate all conflicts, as institutions or individuals may have different responses to an issue, - and '...there will always remain a tension between tourism development and protection of important cultural and natural heritage asset' (Engels \& McCool, 2000: 73) - but the plan should include provision for these potential tensions, and for the different users of the site.

Management plans for WHSs such as Hadrian's Wall are useful for longterm strategy, setting out management principles and future vision, but they rarely cover practical work plans in any detail. This is the responsibility of organisations and individuals involved in managing specific areas of the WHS, whether their areas fall within a statutory designation or are part of the wider landscape. Management plans usually cover a five year period and so cannot plan for unforeseeable events. For example, the outbreak of foot and mouth disease in 2001 had a devastating impact on the tourism and agricultural economy of the area. The opening of the National Trail in 2003 and the increase in visitors to concentrated parts of the WHS has had a profound impact on the conditions of some of the footpaths along the Wall. Whilst visitor numbers to Roman forts and museums along the Wall have remained relatively static (664,624 in 2003 and 594,494 in 2006: National Trails, 2008), the number of long distance walkers using the National Trail has risen significantly (from 3,720 in 2003 to 6,667 in 2006: National Trails, 2008). Much preparation was done before the opening of the Trail, but the extended season, the rise in visitor 
numbers and the fact that, as a public right of way, the Trail cannot be closed, brought further challenges for managers along the Trail. Organisations responded to both these issues in different ways: Vindolanda ${ }^{\text {iii }}$ was the one site along the Wall to remain open during foot and mouth disease; and, for the footpaths, although a values-based approach is promoted in the management plan, questions have arisen as to what should take priority on some areas of the public right of way. This will be discussed in the case study.

In order to make sense of differences and potential tensions of the practical interpretations and application of the Hadrian's Wall Management Plan (2008-2014), this article uses the framework set out by Elson et al (1995) who advocate a valuesbased system. Their framework considers six factors which they deem to be crucial for good practice and for balancing interests. These are, firstly, assess the 'state of the environment', taking into account conditions at the site/s and the possible impact of visitors on that environment. Secondly, achieve 'clarity of purpose' by setting out objectives and having a realistic framework for future actions. Thirdly, use 'participatory management' to ensure regular, on-going engagement and involvement of relevant interested parties when and where needed. Fourth, recognise the 'importance of voluntary agreements', emphasising their value and also making sure that organisations, governing bodies and individuals have methods of selfregulation and are able to adhere to them. Fifth, ensure 'local involvement' by building and maintaining relationships and on-going liaisons with local communities and those who work in the area. And finally, monitor and review progress - use a flexible, though systematic and continual approach to monitoring to help inform future management decisions. These factors represent a simplified interpretation of a 
values-based approach. Some factors will be more important in some areas than others. Furthermore, complexities relating to each factor are too numerous to address here, but the principles are applied to a case study to explore, using the successive Management Plans as the foundation, the approach in practice in the WHS.

\section{Methodology}

The findings presented here are drawn from a larger study on Hadrian's Wall WHS (Bell, 2008). This article presents previously unpublished primary and secondary data and grey literature, such as management documents, related to the WHS and other protected areas within it to consider how the WHS is managed. Primary data are drawn from a series of interviews which were carried out at the end of 2005 and throughout 2006. 55 people were interviewed, with many being interviewed more than once. These included visitors, residents, farmers, small business owners, and managers and supervisors working within the WHS. The data presented in this article refer to managers and supervisors $(n=7)$ who were, at the time, directly involved in the management of the WHS in the central part of the Wall (and in some cases, other parts). Qualitative semi-structured interviews were the most effective way of gathering evidence about positive and negative experiences of management of Hadrian's Wall. This series of interviews accumulated a level of detail that would not have been possible in a survey. Analysis of the data was supported by Atlas.ti software. The focus of this article is on challenges at the time of interview (20052006). The concerns of managers expressed in these interviews have since been addressed in the 2008-2014 Management Plan and show, as explained below, that a 
site like Hadrian's Wall (that is multiple-use, with many stakeholders and with designated areas within its boundaries) needs to be managed in a pluralistic, progressive way.

\section{The evolution of management planning for Hadrian's Wall WHS}

The landscape that Hadrian's Wall traverses has been managed for centuries for agriculture, quarrying and other activities. This article considers the intricate process of developing an appropriate management plan for the WHS. The analysis must necessarily be set in context of previous plans and the subsequent developments to demonstrate the importance of a pluralistic approach. This section demonstrates how the approach to management has evolved and what this means for the WHS and, potentially, for other multiple-use sites. The aim of the section is to illustrate the changes that have occurred over successive management plans for the WHS, to show why there has been an increased emphasis on a pluralistic approach. The designation of WHS status brought with it an explicit move towards managing Hadrian's Wall as one destination to encourage the preservation and conservation of the archaeological remains. This had been suggested in earlier documents, but inscription into WHS status meant a coherent management plan for the whole of the Wall was needed.

The Dartington Amenity Research Trust (DART) Report (1976) was commissioned by the Countryside Commission and highlighted the need to manage Hadrian's Wall in its entirety. It also recommended the setting up of the Hadrian's Wall Consultative Committee (HWCC) (Countryside Commission, 1976) which was established in 1977 with representatives from bodies involved in the management and implementation of policies relating to Hadrian's Wall (Hadrian's Wall Consultative Committee, 1984) ${ }^{\mathrm{i}}$. In 1984, in response to the DART report, the 
Consultative Committee published The Strategy for Hadrian's Wall. This set out methods for safeguarding elements of Hadrian's Wall: the Wall; major sites; the Wall and its setting; access and communications; and, visitor services. This strategy provided the foundation for structured partnership working with a wide range of stakeholders across the length of the Wall and where the future management of the Wall was established, prior to its inscription to WHS status.

The first Hadrian's Wall WHS Management Plan was published in 1996. The plan focused on the archaeological core of the Wall, describing the WHS as 'Hadrian's Wall Military Zone' (English Heritage, 1996). This plan did recognise values of different areas within the WHS but there was still a strong emphasis on the Roman archaeology. The 1996 plan documented the unique landscape and 'natural' beauty of the central section, acknowledging its importance for visitors, but also that the monument was prone to damage due to overuse by visitors walking along the Wall route. The 2002-2007 Hadrian's Wall WHS Management Plan reflected a further shift in the Wall's management approach. This plan displayed a growing appreciation of the wider cultural landscape and all that contributes to it, not just the Roman monument. This Management Plan referred to the WHS as the both the 'Site' of the Wall and the 'Wider Setting' for the first time ${ }^{\mathrm{v}}$. For the whole site, four main components were recognised: archaeological and historic values; natural values; contemporary values; and, World Heritage values (English Heritage, 2002; Mason et al., 2003); these values are set out in Table 1. The 2002-2007 plan showed an explicit attempt to balance traditional and contemporary-use values of the WHS: it acknowledged the need to recognise the significance of other users of the WHS that contributed to its development. However, it appeared to continue to separate 
archaeological and historic values from those that have also historically contributed to shaping the landscape, such as agriculture and land use. This traditional approach to different values in such a significant strategic document does not promote collaborative working and could, perhaps, reflect some of the levels of misunderstanding between stakeholders.

\section{[Table 1 inserted somewhere near here]}

At the time of study the 2008-2014 Management Plan was being written and it responds to the continuing need to take wider values of the WHS into account. As Table 2 illustrates, the emphasis shifted further from the safeguarding of the archaeology to recognise in more detail other, less tangible, values of Hadrian's Wall. For example, it clearly states the social value of the area, maintaining that it is "valued by those who live and work in the area as part of their geographic and social identity" (HWH, 2008a:30). The criteria set out in the 2002-2007 Management Plan are comparable to the European evaluation criteria of significance (Deeben et al., 1999, as cited in Carman, 2000). The change in the values for the 2008-2014 Management Plan demonstrate the realisation that values for Hadrian's Wall WHS need to be specific for the Site, so that they are directly relevant to the site, rather than a generic list. Perhaps most significantly, the values of the 2008-2014 Management Plan explicitly acknowledge that many of the values cannot be considered in isolation, conservation of one can be dependent on another and also, values overlap and connect. For example, archaeology and history are included across all of the values, and landscape, in different contexts, is included in evidential, aesthetic, communal and natural values. Furthermore, the Plan includes detailed appendices that set out the policies for managing specific areas (spatial, discipline 
and designations, such as the National Trail), issues and actions to be taken and where appropriate, who is responsible for the actions: it is very close to being a work plan without being prescriptive and by being so, contributes to clarity of purpose for the management of Hadrian's Wall.

\section{[Table 2 inserted somewhere near here]}

The 2008-2014 Management Plan sets out changes that have occurred since the previous (2002-2007) management plan that will have an impact on management approaches. These include: The opening of the National Trail (2003); re-inscription of the WHS (2005) - it is now part of the Europe-wide 'Frontiers of the Roman Empire WHS'; the establishment of Hadrian's Wall Heritage Limited (2006); and, the opening of Hadrian's cycleway - National Cycle Route 72 (2006) (HWH, 2008a:33). Hadrian's Wall Heritage Limited became responsible for overall management of the WHS in 2006. The company integrated previous organisations managing the Wall: the Hadrian's Wall Tourism Partnership, the Hadrian's Wall Coordination Unit and National Trail management into one (not for profit) company that is the 'co-ordinating body for the management and promotion of the WHS' (HWH, 2008a:4). This illustrates progression into assimilation of strategy to produce a pluralistic vision for the conservation of the WHS and its landscape whilst promoting the area for tourism and other recreational activities. This short review of the evolution of strategy and priority over time demonstrates the complexities surrounding the management of large sites which involve multiple users and serve to meet the needs of a range of interested parties. The article now considers how the practices of individuals who are tasked with management and strategy influence, and are influenced by, these processes. 


\section{The practicalities of managing a WHS}

The Hadrian's Wall Management Plan, as a requirement of WHS status, seeks to set out policies and a visionary framework for the WHS, but there is no statutory obligation for managers to adhere to them, more a reliance on voluntary agreements to achieve outcomes (Mason et al., 2003). Despite a sound management plan built on a values-based approach, the analysis shows that, in practice, a pluralistic approach can be difficult to achieve. On the surface, consensus of opinion is apparent, but implicitly there are many tensions, individuals have difficulty putting aside professional and personal values and often take a moral standpoint from their own perspective (Church et al., 2007), resulting in an inability to make informed decisions about immediate management issues. This section begins by introducing the main issue for managers in 2006, degradation to the monument by overuse of the footpaths along the National Trail. It explores how managers position themselves in relation to their values and how, in practice, their values can affect their decisions and their openness to negotiation with other belief systems. A specific example, King Arthur's Well, is then presented to illustrate how these differing opinions can be resolved in practice. The discussion concentrates on issues raised in part of the central section of the Wall, associated with the National Trail and within the National Park (see Figure 1). This is the most frequently visited section, has the most excavated remains, is a dramatic landscape - and where many challenges arise.

The key challenge discussed by managers was the management of footpaths along the linear monument, brought about by increased use due to the National Trail. The example at King Arthur's Well illustrates the complexity of issues that one small area can have, how different institutions and organisations focus their values 
on diverse evaluative criteria and how the issue has been resolved (O'Neill, 1997). Brian, a manager along the Wall, took a traditional approach, focusing on one perspective to the management of the WHS. His priority was the universal value and the archaeological integrity of the site, as by profession he is an archaeologist and historian. He stated that the Roman archaeology should take precedence over anything else: 'the management plan is to protect the archaeology, the World Heritage Site, so if two things meet...it's the World Heritage Site which has the priority.' Brian believes that a tension remains between WHS designation (and the 2002-2007 Management Plan) and practical application of management along the Wall. He stated that UNESCO has expectations of what a WHS Management Plan should be and this can cause confusion and conflict:

'...I think there's a difference to what UNESCO want, they want a management plan related to the World Heritage values and that's it...the management plan is a way of actually protecting the UNESCO values in the end, because if you don't have that it is completely irrelevant, so it may look fine in UNESCO speak but on the ground it's a total mess and nobody works together and it becomes a shambles.'

So, although Brian takes a focused, one perspective approach to the management of the WHS, he accepts that, in practice, the language and structure of (previous: e.g. 1996; 2002-2007) Hadrian's Wall Management Plans may not be very useful, or clear to those unfamiliar with its content. Another manager, Carl agreed, but put the confusion down to a lack of consultation at the grass-roots: 'They still need consultation at grassroots level...are they prepared to listen to the likes of ourselves who are on the ground, who listen to the landowners who have been here for 
generations...it does need consultation at grassroots level.' The response to this has been widening of consultation and involvement of stakeholders across the WHS. For example, as well as the Management Plan Committee that, amongst other things, oversees the strategic direction and develops policies and codes of practice for the WHS, the 2008-2014 Management Plan has also seen the establishment of interest groups within its management structure, representing different organisations and individuals who are responsible for everyday issues in the WHS. Their responsibilities include: producing annual action plans, advise on issues through monitoring, and provide further collaboration between different interests $(\mathrm{HWH}$, 2008a). The groups are: planning and protection; conservation, farming and land management; access and transport; visitor facilities, presentation and tourism; education and learning; and, research (HWH 2008a:3-4). The purpose of the groups is to improve shared understanding which will enable future management to be coordinated more fully and progress ideas with the aim of more effective valuesbased management of the WHS with a shared vision. The interest groups have the potential to be a pivotal instrument in realising the scope of having plural voices feeding into the management of the WHS in a structured way. These groups can contribute to all six factors set out by Elson et al (1995) in their framework, demonstrating their importance, both for representation of different interests and for information dissemination to and from the Management Plan Committee.

Anthony works in the central section of the Wall. His preference for the management of the Wall is value pluralism in the strictest sense: he does not believe that any one value should take precedence over another. This comes from his indepth knowledge, not just of the Roman remains, but also the wider landscape and 
land uses of the WHS. In his interview, he outlined the need for an holistic approach towards managing the Site, with particular reference to management of the National Trail:

'It's a World Heritage Site because of the archaeology, so archaeology is obviously going to be a very high priority, but particularly in this central section of Hadrian's Wall there's a lot of other things as well. It's a very special landscape...and the way the Trail is being managed at the moment, it's too narrowly focused on the archaeology and what we are calling for is a more balanced approach. We're not saying that the archaeology is not important by any means, it is, it's very important but so are a lot of other things.'

Anthony advocates a pluralistic approach, taking the values of the site as a whole with trade-offs negotiated in light of this. He also argues that some conflicts derive from personal values and the inability of some managers to set aside their own priorities for the benefit of the wider WHS, and so conflicts occur. It is to be expected that people will base judgements and may make decisions based on their values, knowledge and expertise. Producing consensus is difficult when people are not willing to give any ground (Carman, 2000). To illustrate this point, I will now give an example of how difference of opinion and the tensions that produces can be overcome.

The popularity of the National Trail with the general public has resulted in more footpath repairs than was originally anticipated, as Edward explained: 
'I mean the Trail has been up and running a couple of years now and I don't think we realised how popular it would be. I mean yes we did a lot of preparation work beforehand, a lot of footpath repair... and that following November, December [2003] it was still being heavily used...'

The Hadrian's Wall Path National Trail has increased visitor numbers and hence the pressure on some concentrated areas that are archaeologically sensitive within the WHS. The impact of visitors using the National Trail has been detrimental, demonstrating an increased need to balance heritage and landscape values, as Edward pointed out:

'...it's a bit of catch 22 isn't it, you want people here because its bringing money into the rural economy...but then you have these counterarguments, well it is a monument, it is getting damaged and it's a difficult balancing act.'

At this time (2005/6), the management of the WHS did not fully take into account the 'State of the environment' and the potential impact of increased visitors (Elson et al., 1995). Monitoring and review of the state of the footpaths was done by workers and volunteers on the Trail, however, it did not lead to the intervention work getting done. The managers of the Trail prepared for its increased use but, at the time, were unable to do 'running repairs' due to consent being required before any work could be carried out on the monument ${ }^{\mathrm{vi}}$ which in some areas led to unnecessary degradation of the monument. Part of the agreement for the National Trail was that it should not travel over any existing archaeology and parts of the public rights of way have been diverted because of this (Countryside Commission, 1993; HWH, 2008a). However, the archaeology of Hadrian's Wall is not limited to the Wall itself - other 
associated ruins and earthworks are a fundamental part of the WHS. With designations such as SSSIs within the WHS, if a footpath needs to be diverted in order to rest the footpath it is not always a straightforward task. Moreover, parts of the Trail are on steep slopes and have thin soils, making repairs difficult. Several methods have been tried and are being used for managing footpaths to cause least damage to the archaeology or detriment to the landscape, but there remains differing opinions to which is best. Methods include: resting and diverting footpaths to maintain the grass sward ${ }^{\mathrm{vii}}$ and the use of different materials for, arguably, more sustainable management, including: stone pitching ${ }^{\text {viii }}$, shale surface and geotextiles ${ }^{\mathrm{ix}}$. Opinions on the most appropriate method at a site can cause conflict and also delay remedial actions being taken if agreement cannot be reached swiftly. In order to focus the analysis, a discrete example is presented to show how a pluralistic management approach works in practice. The location, King Arthur's Well, illustrates some of complex issues and conflicting interests facing managers working along the Trail and discusses how diverse values can be negotiated in practice to an agreed outcome.

\section{[Figure 2 inserted somewhere near here]}

\section{King Arthur's Well-diverting the footpath.}

King Arthur's Well is a Scheduled Ancient Monument located on a steep slope within the WHS. At the bottom of the slope, adjoining King Arthur's Well, there is a SSSI (Alloa Lea) which is protected by European legislation, the Habitats Directive. A disused public footpath runs through the SSSI and whilst within the National Park, the area is in private ownership (area highlighted in Figure 1). The key issue at King Arthur's Well, especially on the slope, is the impact of an increased number of 
walkers using the National Trail causing serious erosion and having a detrimental effect on the archaeology. The dispute centred on the route of the footpath - whether the path should be permanently diverted away from King Arthur's Well and through the SSSI - and if it was to continue through King Arthur's Well, what materials should be used to repair the footpath.

Although WHSs are not currently protected under legislation, they are recognised by international convention, or agreement, for conservation and preservation of the site's outstanding universal value, so putting emphasis on 'negotiated voluntary agreements' between different parties (Church et al., 2007:215). Due to the number of stakeholders involved at King Arthur's Well and conflicting interests and values, no consensus or agreement could be reached about either the route of the footpath or the materials that should be used. The archaeological community argued that the footpath should be diverted through the SSSI and nature conservationists (and others) argued that stone pitching should be used to repair the existing footpath that runs through King Arthur's Well. Brian is against stone pitching because, he argues, it causes irreparable damage to the monument, which is counter to his expectation of the use of the archaeological resource (Jacob \& Schreyer, 1980) and so was not prepared to compromise his professional values:

'...although it's a natural material, it is still a structure, it's still an artificial structure, ...it's natural material, but it's a structure....and it's the impact on the [archaeology]...[It would be] a hard line in a soft landscape here...pitching in amongst basically grass, there's not a lot of stone there...so I am very much against pitching there' 
He was in favour of diverting the footpath through the SSSI; he considers that, due to the archaeology taking precedence due to WHS status that this, in all circumstances, should have priority over other values:

'It's a World Heritage Site so that should come first. So there should be a refusal [at King Arthur's Well] because of the impact ...you've got to make a value judgment and you say well actually the archaeology is the World Heritage Site so normally we would try to safeguard [the SSSI], but where there's a conflict that should, this one should take priority'.

So, even though Brian is aware of the rare habitat or species present at the site, he appeared unable to reconcile the different values of the site and take a pluralist view - it was against his 'better judgment'. He could not separate his professional responsibility and his own principles and value judgement from the argument - in fear, it seems, of making a disciplinary mistake that might be irreversible. Carl argued for stone pitching on the existing footpath across King Arthur's Well, saying that it was the most sustainable option for the site, and it had been 'tried and tested' on other susceptible slopes in the WHS:

'The pitching will last beyond our lifetime, so yes we've had a little bit of a challenge...on a day to day basis, we're balancing all these different aspects of the Wall, we're quite used to it and that's what frustrates us, when we see somebody coming in with a narrow focus, managing something quite narrowly and then not listening'.

Again, Carl calls for others to widen their views, take other perspectives into account in order to try and balance, as far as possible, all the conflicting values of 
stakeholders of the WHS. With the lack of a voluntary agreement being reached, Frank considered that the issue at King Arthur's Well should be resolved externally and at a senior level of decision-making due to the intractable opposition of values of those directly involved. If this did happen, then this site could be used as a test case for the management of the rest of the WHS:

'We have an almost intractable problem at King Arthur's Well with a SSSI there you've got nature conservation legislation, archaeological legislation both designed to protect their own interests and they are at loggerheads: which legislation takes primacy? That, I think, needs a discussion at ministerial level'

Frank said that the issue at King Arthur's Well was proving difficult to resolve due to lack of negotiation by interested parties - their institutional (and sometimes personal) value systems were stopping them from reaching agreement (Church et al., 2007; Ravenscroft, 2004). An external decision would also lessen any blame being placed on those directly involved. After extended negotiations and institutions 'standing their ground' in order to protect their own values and putting their own principles first, (Jacob and Schreyer, 1980) a decision was made to stone pitch the existing path instead of permanently diverting the path through the SSSI and so protect it from any further damage from walkers. However, this judgement is not as straightforward as it first seems. Firstly, the decision took time: over two years after the opening of the National Trail. Secondly, in order to come to an agreed outcome for this site, both parties had to make compromises from their own management perspective, but both gained from the final decision. 
There is an archaeological structure within the SSSI that had not been assessed. As part of the agreement for the works to go ahead, an evaluation of the structure was factored into projects costs by the conservationists. Through this assessment, the archaeological community were able to build on the archaeological knowledge of Hadrian's Wall, and have a footpath that protects any underlying archaeology and keeps walkers off the monument; conservationists were able to protect the acid grassland upland habitat designated in the SSSI by preventing the site being used as a footpath; and, the footpath managers were able to construct a sustainable path that minimises degradation to the archaeology and does not detract from the landscape. A stone pitched path was chosen as the best option in this case as the method uses natural, used stones to form a path. This requires some digging out of the surface soil in order to make a foundation for the large stones. The line of the path follows the natural contours of the slope, which over time settle into the landscape and become barely visible from a distance. Whilst digging the initial foundations may cause some damage to the archaeology, this is offset by the longer term protection of any underlying archaeology from further degradation. Erosion by walkers is minimised as long as they stick to the path, which they are likely to do given the steepness of the slope. Ultimately this problem could not be resolved until all parties agreed that the decision needed an objective view, to be taken by those not working directly in the WHS. This involved representatives at a more senior level of decision-making within the organisations that were participating in the management of this site. The aim was to take personalities out of the equation and so the personal out of the decision, with the sustainable management of the WHS at the centre of any decision. The process to reach this agreement was protracted and one of the reasons it was determined at such a senior level within institutions was the significance of the 
site in a number of fields. The final agreement involved negotiation and trade-offs and as shown had to take a range of views and values into consideration. The outcome was the best one for the site, rather than the organisations or individuals involved in the process. In its own way, the resolution set a precedent for other major judgements within the WHS: considering the values of the site over those of organisations or individuals.

\section{Conclusion}

The analysis presented in this article of Hadrian's Wall WHS, illustrates how a pluralistic values-based approach can work. By definition this argument signifies a rejection of uni-dimensional 'discipline based' approaches which are value-blind to other interests, or interest-based approaches where inter-relationships are necessarily combative and lead to unsatisfactory outcomes for too many stakeholders. Pluralistic approaches to site management can be very successful for sites that have multiple users providing that stakeholders are able to work to a shared vision. A strategic document, such as a management plan, can form a basis for negotiation on issues as they arise. The evidence suggests that three criteria have to be met if a pluralistic values-based approach is to be successful: firstly, the plan must be developed in partnership to take into account the views of a range of stakeholders and produce agreements based on compromise; secondly, the plan must be flexible to take into account contingencies; and thirdly, there is a need for partnerships to be clearly structured so that agreements made can be implemented.

The above analysis has shown how agreement can be reached by considering the values of different stakeholders through compromise. This can be difficult due to 
organisational and individual values and disciplines of stakeholders, and pressures that they face managing areas with different priorities. The case study has shown that sometimes, for decisions to be made, support external to the immediate partnership may be needed. This is not a failing of the partnership, moreover, it is an acknowledgement by the partnership that some decisions are beyond their scope. The decision in the case study illustrates an outcome based on compromise for the benefit of the site. It has been argued that, by definition, management plans must be flexible and responsive to change. The evolution of the Hadrian's Wall management plan has shown that continual review, refinement and updating of a management plan is vital as more knowledge and understanding of a site is accumulated. Consequently, lead organisations and their stakeholders need to accommodate contingencies. For example, the development and opening of the National Trail involved stakeholders also responsible for the management of the WHS. The National Trail brought with it challenges, such as increased footpath erosion that managers had to be responsive to. One implication of the National Trail was that its management had to be included in the Hadrian's Wall WHS management plan. Initially, due to timings of the production of the plan, this had to be done informally. WHS management has an obligation to include these (and other) changes in their management strategy.

Professional (and sometimes personal) discourse will continue to conflict and so challenges within partnerships are always going to be present. This is an endemic difficulty for partnerships and one that partners have to learn to deal with in their own way. For example, managers of the WHS will continue to debate the question of what materials are most appropriate for repairing footpaths along the Trail but, as the case study has shown, on a case by case basis they are able to reach an agreement. 
However comprehensive a management plan is, in five years, policies - internal and external - are likely to shift or change. Such plans are essentially 'living documents' that have to include sufficient flexibility to accommodate social, economic, political and scientific change. Organisations and their stakeholders need to have systems in place that can overcome unforeseen challenges or specific issues.

For successful management, and to ensure that a procedure is in place to make decisions, partnerships have to be structured. Producing structured partnerships is, as shown in this study of Hadrian's Wall, a long-term project. Even though the original management documents set out a structure of partnership working and attempted to establish a pluralistic approach, it has taken decades to evolve. Structuring partnerships is not the same as producing partnerships with fixed memberships. Strategic and work plans of institutions, organisations and individuals within the site, may change over time and any overall strategy will need to reflect this. The 2008-2014 Hadrian's Wall Management Plan aims to be fully inclusive of a wide range of stakeholders, at all levels of involvement. Furthermore, the integration of values has resulted in a wider appreciation of an holistic, values-based approach to site management. The inclusion of structured interest groups in the Hadrian's Wall management strategy has the potential to progress the notion of a values-based approach even further.

This study of Hadrian's Wall WHS strongly suggests that the factors set out by Elson et al. (1995) remain relevant for managing protected areas. The framework utilises, and simplifies a values-based approach, advocating the need for activities including, active engagement with and by all stakeholders; clarity of purpose; local involvement; and, continual monitoring and review to help inform future 
management decisions. These principles provide a foundation for management of similar multi-purpose sites which have multiple objectives. The essence of the approach is to customise and build management plans that are appropriate for each site and its users. It has been demonstrated that such an approach is quite different from purely discipline-based or interest-based plans that produce dogmatic arguments which, in turn, reduce the prospects for the necessary level of compromise and flexibility to meet the interests of key stakeholders. Necessarily, the pluralistic values-based management approach is offered as a broad framework to ensure that the focus of management plans are set in the context, significance and activities of the site. In turn, users of the site need to be made aware of and be prepared to accept management objectives where appropriate.

\section{Acknowledgements}

The research was carried out as part of an ESRC funded doctoral study and would not have been possible without the generosity of the people who took part. Thank you to the reviewers for such constructive comments on earlier drafts of this article. Thanks also to Tony Chapman for guidance and inspiration.

\footnotetext{
' UNESCO website: www.unesco.org/en/about

ii Hadrian's Wall Path National Trail opened in 2003 and is one of 15 long distance walking routes across England and Wales.

iii Vindolanda is in the central part of the WHS and is run by an independent Trust.

iv The HWCC is now the Hadrian's Wall Management Plan Committee with similar consultation responsibilities relating to the overseeing of the WHS Management Plan.
} 
${ }^{v}$ Up until the current management plan (2008-2014), the boundaries had been referred to as the Site and the Setting, rather than the Site and the buffer zone - probably relating back to the HWCC (1984) document: The Strategy for Hadrian's Wall.

vi All intervention work on Hadrian's Wall usually requires Scheduled Monument Consent, meaning that individual consent is required before any work at all can be carried out. The National Trail managers now have 'generic consent' to carry out management and immediate repairs along the Trail (for further details see HWH, 2008).

vii Land covered with grassy turf.

viii Installing large, worn, natural stones into a slope to form a path (Rimmington, 2004:32).

ix Geo-textiles are plastic surfaces that have to be dug into the footpath. They are designed to spread the load and reduce compaction of the soil which, in turn, assists growth of a grass sward (Rimmington, 2004: 32)

\section{References}

Anderson, C. (1997) Values-based management. Academy of Management

Executive. 9 (4), 25-46

Bell, V.R. (2008) Not just a load of old stones: Visual encounters with Hadrian's Wall. (Doctoral thesis) Newcastle Upon Tyne: Newcastle University.

Birley, A.R. (1976) Hadrian's Wall. London, Department of the Environment, HMSO.

Breeze, D. (2006) Hadrian's Wall. English Heritage Guidebook. London, English Heritage.

Bromley, P. (1990) Countryside Management. London E \& FN Spon.

Carman, J. (2000) Archaeology and Heritage: An Introduction. London, Continuum.

Chambers, S.A \& Carter, T. (2008) William. E. Connolly: Democracy, Pluralism and Political Theory. New York: Routledge.

Church, A., Gilchrist, P \& Ravenscroft, N. (2007) Negotiating recreational Access Under Symmetrical Power Relations: The Case of Inland Waterways in England, Society and Natural Resources 20 (3) 213-227 
Countryside Commission (1993) (CCP 409) The Hadrian's Wall Path. Submission to the Secretary of State for the Environment. Northampton, Countryside Commission.

Countryside Commission (1976) (CCP 98) Hadrian's Wall. A strategy for conservation and visitor services. Northampton, Countryside Commission.

Elson, M.J., Heaney, D. \& Reynolds, G. (1995). Good Practice in the Planning and Management of Sport and Active Recreation in the Countryside. London: Sports Council and Countryside Commission.

Engels, P.F.J \& McCool, S.F. (2000) Tourism in National Parks and Protected Areas. Planning and Management. Wallingford, CABI Publishing.

English Heritage (2002) Hadrian's Wall World Heritage Site Management Plan 2002-2007. London, English Heritage.

English Heritage (2001) Hadrian's Wall World Heritage Site Management Plan 2001-2007 Summary of Consultation Draft. London, English Heritage.

English Heritage (1996) Hadrian's Wall World Heritage Site Management Plan 1996-2001. London, English Heritage.

Galston. W.A. (2002) Liberal pluralism: The implications of value pluralism for political theory and practice. Cambridge: Cambridge University Press.

Garrod, G. \& Whitby, M. (2005) Strategic Countryside Management. Oxford: Elsevier.

Gilchrist, P. \& Ravenscroft, N. (2011) Paddling, property and piracy: the politics of canoeing in England and Wales, Society and Sport 12 (2) 175-192

Hadrian's Wall Consultative Committee (1984) The Strategy for Hadrian's Wall. Newcastle upon Tyne, Countryside Commission.

Hadrian's Wall Heritage Ltd [HWH] (2008a) Frontiers of the Roman Empire World Heritage Site. Hadrian's Wall Management Plan 2008-2014. Retrieved from: http://www.hadrians-

wall.org/ResourceManager/Documents/Hadrian's\%20Wall\%202008-2014\%20-

$\% 20$ Greyscale $\% 20$ text $\% 20 \& \% 20$ appendices.pdf

Hadrian's Wall Heritage Ltd [HWH] (2008b) An Introduction to Hadrian's Wall Management Plan 2008-2014. Retrieved from: http:/www.hadrianswall.org/ResourceManager/Documents/Management\%20Plan\%20Introductory\%20d ocument.pdf

Jacob, G.R. (1980) Conflict in Outdoor Recreation: A Theoretical Perspective, Journal of Leisure Sciences 12 (4) , 368-380 
London, M. (1999) Principled leadership and business diplomacy. A practical, values-based direction for management development. Journal of Management Development 18 (2), 170-192

Mason, R., MacLean, M.G.H. \& M. de la Torre (2003) Hadrian's Wall World Heritage Site. A Case Study. Los Angeles, The Getty Institute.

National Trails (2008) Economic Impact Report 2003-2007. National Trail website: http://www.nationaltrail.co.uk/hadrianswall/text.asp?PageId=2: Information retrieved 15.09.2010

O'Neill, J. (1997) Value pluralism, incommensurability and institutions in Foster, J.M (Ed) Valuing nature?: ethics, economics and the environment. pp. 75-88 London: Routledge.

Pruzan, P. (1998) From Control to Values-Based Management and Accountability. Journal of Business Ethics 17, 1379-1394

Ravenscroft, N. (2004) Tales from the Tracks: Discourses of Constraint in the Use of Mixed Cycle and Walking Routes, International Review for the Sociology of Sport 39 (1) $27-44$

Rimmington, J.N. (2004) Managing Earthwork Monuments. Hexham, Hadrian's Wall Co-ordination Unit.

Tetlock, P.E., Peterson, R.S. \& Lerner, J.S. (1996) Revising the value pluralism model: incorporating social content and context postulates in Seligman, C., Olson, J.M. \& Zanna, M.P. (Eds) The psychology of values: Ontario Symposium Number 8. pp. 25-51. Mahwah, New Jersey: Lawrence Erlbaum Associates Ltd

Tetlock, P.E. (1986) A value pluralism model of ideological reasoning. Journal of Personality and Social Psychology. 50(4), 819-827

Turley, S. (1998) Hadrian's Wall (UK) Managing the visitor experience at the Roman Frontier. In Shackley, M. (Ed) Visitor Management. Case Studies form World Heritage Sites. pp.100-120 Oxford, Butterworth-Heinemann.

UNESCO World Heritage Site website: http://whc.unesco.org/en/about/ Information retrieved 08.04.11 